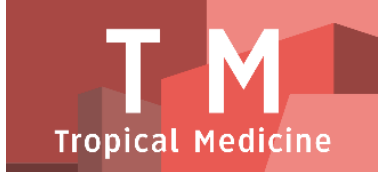

PAPER - OPEN ACCESS

\title{
Aktivitas Hepatoprotektor Ekstrak Etanol Kulit Bawang Merah (Allium cepa L. Corium) Terhadap Mencit Jantan Yang Diinduksi Parasetamol
}
Author
: Aminah Dalimunthe
DOI
: 10.32734/tm.v1i3.252
Electronic ISSN
: 2623-0542
Print ISSN
: 2623-0550

Volume 1 Issue 3 - 2018 TALENTA Conference Series: Tropical Medicine (TM)

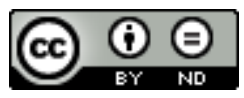

This work is licensed under a Creative Commons Attribution-NoDerivatives 4.0 International License.

Published under licence by TALENTA Publisher, Universitas Sumatera Utara
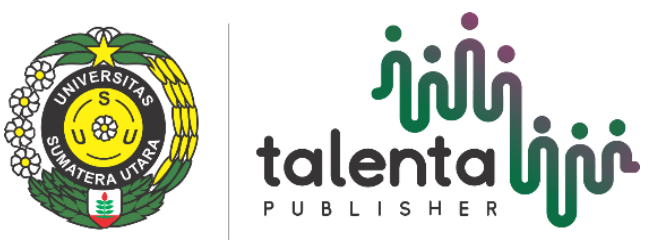


\title{
Aktivitas Hepatoprotektor Ekstrak Etanol Kulit Bawang Merah (Allium cepa L. Corium) Terhadap Mencit Jantan Yang Diinduksi Parasetamol
}

\author{
Janet Bardos ${ }^{\mathrm{a}}$, Aminah Dalimunthe $\mathrm{b}^{\mathrm{*}}$, Urip Harahap ${ }^{\mathrm{c}}$ \\ ${ }^{a b c}$ Departemen Farmakologi Farmasi, FakultasFarmasi, Universitas Sumatera Utara, Medan 20155
}

aminahdalimunthe@usu.ac.id

\begin{abstract}
Abstrak
Metabolit reaktif $N$-acetyl-para-benzoquinoneimine (NAPQI) akan dilepaskan setelah pemberian parasetamol dosis tinggi sehingga dapat merusak hati. Salah satu tumbuhan yang berpotensi sebagai hepatoproktektif adalah bawang merah (Allium cepa L.). Tujuan penelitian ini adalah untuk mengevaluasi aktivitas hepatoprotektor ekstrak etanol kulit bawang merah (EEKBM) terhadap mencit jantan yang diinduksi parasetamol. Enam kelompok perlakuan $(\mathrm{n}=4)$ diberi $\mathrm{Na}$ CMC 0,5\% sebagai kontrol negatif, EEKBM dosis 300, 450, dan $600 \mathrm{mg} / \mathrm{kg}$ bb, dan rutin $20 \mathrm{mg} / \mathrm{kg}$ bb sebagai kontrol positif selama 14 hari secara oral dan diikuti pemberian penginduksi hepatotoksik parasetamol $1 \mathrm{~g} / \mathrm{kg}$ bb. Sampel darah dan hati dikumpulkan untuk pemeriksaan biokimia dan mikroskopik. Kelompok normal digunakan sebagai pembanding. Berdasarkan hasil penelitian menunjukkan bahwa kadar AST dan ALT dihambat oleh EEKBM dosis 300, 450, dan $600 \mathrm{mg} / \mathrm{kg}$ bb dan berbeda signifikan dengan kontrol negatif $(\mathrm{p}<0,05)$ dan melindungi sel hati dari kerusakan. Dapat disimpulkan bahwa EEKBM dosis $600 \mathrm{mg} / \mathrm{kg}$ bb menunjukkan aktivitas hepatoprotektor.
\end{abstract}

Kata kunci : parasetamol, hepatoprotektor, kulit bawang merah (Allium cepa L. Corium)

\begin{abstract}
$\mathrm{N}$-acetyl-para-benzoquinoneimine (NAPQI) metabollite will be released after administration of high doses of paracetamol which can damage the liver. One of the plants that has potential hepatoprotective activity is onion (Allium cepa L.). The aim of this study was to evaluate hepatoprotective activity of outer layer of onion skin ethanol extract of Allium cepa against paracetamolinduced liver damage in male mice. Six groups of mice $(n=4)$ were given CMC Na $0.5 \%$ as negative control, EEKBM at doses of 300,450 and $600 \mathrm{mg} / \mathrm{kg}$ bw, and rutin $20 \mathrm{mg} / \mathrm{kg}$ bw as positive control orally for 14 days followed by induction hepatotoxicity using paracetamol $1 \mathrm{~g} / \mathrm{kg}$ bw. Blood sample and livers were collected for biochemical and microscopic assays. Normal group was used as comparation. Based on the results showed that level of AST and ALT were inhibited by Allium cepa at doses of 300,450 and $600 \mathrm{mg} / \mathrm{kg}$ bw significantly ( $\mathrm{p}<0.05$ ) compare to negative control, and protected hepatic cells from damage. It concluded that Allium cepa at dose of $600 \mathrm{mg} / \mathrm{kg}$ bw had hepatoprotective activity
\end{abstract}

Keywords : paracetamol, hepatoprotector, onion skin (Allium cepa L. Corium.)

\section{Pendahuluan}

Kerusakan hati merupakan efek samping yang disebabkan oleh metabolit parasetamol dosis tinggi dalam jangka waktu lama. Parasetamol dimetabolisme di hati oleh enzim sitokrom P450 menghasilkan metabolit N-acetyl-pbenzoquinoneimine (NAPQI) yang bersifat toksik akibat elektrofilisitasnya. NAPQI yang terbentuk, akan dieksresikan melalui urin setelah didetoksifikasi oleh glutation membentuk konjugat sistein dan asam merkapturat. 
Kekurangan glutation akan mendorong ikatan NAPQI dengan protein hepatosit dan mengakibatkan kerusakan.. Selain itu, jumlah radikal bebas akan ditingkatkan oleh reaksi oksidatif sitokrom P450 sehingga keseimbangan ion kalsium dan cairan di sitosol terganggu serta mengakibatkan depresi fungsi mitokondriadan kematian hepatosit atau nekrosis [1]-[2].

Bawang merah (Allium cepa L.) adalah tanaman umbi-umbian yang digunakan sebagai makanan dan mengandung beberapa nutrisi yang dapat digunakan untuk menyembuhkan dan mencegah sejumlah penyakit. Penelitian sebelumnya tentang senyawa volatile dan non-volatil dari bawang merah, metode identifikasi serta studi terhadap efek biologisnya telah dipublikasikan. Ekstrak bawang merah mengandung senyawa fenolik yang dapat meningkatkan aktivitas antiproliferasi, menghambat mutasi gen dan kanker, antiradang pada lambung, anti kejang serta antidiare. Flavonoid yang terdapat pada ekstrak bawang merah juga menunjukkan aktivitas sebagai antioksidan, pengikat radikal bebas dan antibakteri. Jenis flavonoid yang paling banyak terdapat dalam bawang merah adalah kuersetin bentuk bebas dan terikat dengan glikosida (3',4'-di- dan 4'-glukosida) [3].

Penelitian sebelumnya menunjukkan bahwa parameter fungsi hati seperti alanintransferase (ALT), serum bilirubin total (TBS,) aspartat transferase (AST), alkalinfosfatase (ALP) dan laktat dehidrogenase (LDH) tikus albino jantan galur Wistar yang diinduksi parasetamol dosis $750 \mathrm{mg} / \mathrm{kg}$ dapat diturunkan oleh pemberian ekstrak methanol umbi bawang merah dosis 200, 300 dan $450 \mathrm{mg} / \mathrm{kg}$ secara signifikan (p < 0,05). Studi juga dilakukan terhadap histopatologi jaringan, berdasarkan efek antioksidannya melawan spesies oksigen reaktif yang menjembatani kerusakan jaringan [4].

Aktivitas antioksidan bawang merah menurun secara signifikan dari lapisan terluar hingga lapisan terdalam. Kadar flavonoid lebih tinggi pada kulit bawang merah dibandingkan umbinya. Hal ini tentu menarik perhatian untuk memanfaatkan kulit bawang merah yang sering dibuang dalam proses pengolahan sebagai sumber komersial senyawa fenolik. Penelitian sebelumnya menunjukkan bahwa jumlah senyawa fenolik dan kuersetin yang terdapat dalam kulit lebih tinggi 3-5 kali dari umbinya, sehingga mengindikasikan bahwa kulit bawang merah memiliki potensi untuk digunakan sebagai antioksidan dan antimikroba dalam makanan, kosmetik dan industri farmasi [3]. Berdasarkan uraian diatas peneliti ingin mengetahui aktivitas hepatoprotektor ekstrak etanol kulit bawang merah (EEKBM) terhadap mencit jantan yang diinduksi parasetamol.

\section{Bahan dan Metode}

\subsection{Pengumpulan Sampel}

Sampel kulit bawang merah dikumpulkan secara purposif dari penyuplai bawang merah di Jalan Kemenangan No. 164, Kelurahan Sidorejo Hilir, Kecamatan Tuasan, Medan Sumatera Utara. Sampel diidentifikasi di Herbarium Medanense (MEDA) Universitas Sumatera Utara.

\subsection{Hewan Percobaan}

Sebanyak 24 ekor Mencit (Mus musculus) jantan dengan berat badan 20-30 gram dan sehat digunakan sebagai hewan percobaan dalam penelitian ini. Mencitdiaklimatisasi selama 2 minggu dengan tujuan untuk menyeragamkan makanan dan hidupnya dengan kondisi yang serba sama sehingga dianggap memenuhi syarat penelitian dan setelah mendapat persetujuan komisi etik Departemen Biologi Fakultas matematika dan Ilmu Pengetahuan Alam USU Nomor 402/KEPH-FMIPA/2015.

\subsection{Pembuatan Ekstrak Etanol Kulit Bawang Merah}

Ekstrak etanol kulit bawang merah diperoleh melalui proses maserasi menggunakan pelarut etanol 96\% dengan cara sebagai berikut : serbuk simplisia kulit bawang merah sebanyak $500 \mathrm{~g}$ dimasukkan ke dalam maserator dan direndam dengan etanol 96\% sebanyak 3,75 L, kemudian ditutup dan dibiarkan selama 5 hari terlindung dari cahaya sambil sering diaduk. Rendaman diserkai dengan kain flanel dan diperas. Ampas direndam kembali dengan etanol 96\% hingga $4 \mathrm{~L}$ dan dipindahkan ke dalam bejana tertutup, dibiarkan di tempat sejuk, terlindung dari cahaya selama 2 hari. Dienaptuangkan atau disaring. Pelarut dipekatkan dengan rotary evaporator hingga diperoleh ekstrak kental. 


\subsection{Uji Aktivitas Hepatoprotektif}

Hewan uji dibagi atas 6 kelompok dan masing-masing terdiri dari 4 hewan percobaan,yaitu :

I. kelompok normal, hewan uji tidak diberi perlakuan apapun selain makanan dan minuman secara ad libitum.

II kelompok kontrol negatif, hewan uji diberikan suspensi Na CMC 0,5\%.

III kelompok kontrol positif, hewan uji diberikan suspensi rutin $20 \mathrm{mg} / \mathrm{kg}$ bb

IV kelompok perlakuan, hewan uji diberikan EEKBM $300 \mathrm{mg} / \mathrm{kg}$ bb

$\mathrm{V}$ kelompok perlakuan, hewan uji diberikan EEKBM $450 \mathrm{mg} / \mathrm{kg}$ bb

VI kelompok perlakuan, hewan uji diberikan EEKBM $600 \mathrm{mg} / \mathrm{kg}$ bb

Sediaan diberikan secara oral kepada hewan percobaan, sekali sehari selama 14 hari. Parasetamol $1 \mathrm{gr} / \mathrm{kg} \mathrm{bb}$ diberikan kepada semua hewan uji, 6 jam setelah pemberian sediaan di hari ke 14. 24 jam setelah pemberian parasetamol, mencit didislokasi untuk diambil sampel darah dan organ hatinya untuk diperiksa kadar ALT, AST, makroskopik dan mikroskopik hati.

\subsection{Analisis data}

Data yang diperoleh kemudian diolah secara statistik dengan menggunakan One Way Anova untuk membandingkan antara masing-masing kelompok. Untk megetahui perbandingan efek antar perlakuan, maka dilakukan analisis lanjutan, yaitu Post Hoc Test $(\mathrm{P}<0,05)$.

\section{Hasil Dan Pembahasan}

Pemberian parasetamol dosis tinggi meningkatkan jumlah NAPQI hasil metabolism enzim sitokrom P450 di hati. Metabolit ini akan didetoksifikasi oleh glutation menghasilkan konjugat sistein dan asam merkapturat sehingga dapat diekskresikan melalui urin. Kelebihan NAPQI di hati akan menyebabkan terjadinya kerusakan hati yang ditaandai dengan kenaikan kadar AST dan ALT. Hasil pengukuran ALT dan AST dilakukan pada hari ke-15, 24 jam setelah pemberian parasetamol (Tabel 1)

Tabel 1. ALT dan AST mencit setelah diinduksi parasetamol (Mean $\pm \mathrm{SE})$

\begin{tabular}{lll}
\hline Kelompok & ALT (IU/L) & AST (IU/L) \\
\hline Tanpa perlakuan & $139,77 \pm 17,15$ & $210,85 \pm 14,98$ \\
Na- CMC 0,5\% & $1369,87 \pm 101,20^{\mathrm{a}}$ & $2086,35 \pm 177,36^{\mathrm{a}}$ \\
Rutin $20 \mathrm{mg} / \mathrm{kg} \mathrm{bb}+$ parasetamol & $193,77 \pm 9,08^{\mathrm{b}}$ & $354,22 \pm 17,28^{\mathrm{b}}$ \\
EEKBM $300 \mathrm{mg} / \mathrm{kg}$ bb + parasetamol & $755,17 \pm 15,25^{\mathrm{ab}}$ & $1051,00 \pm 23,57^{\mathrm{ab}}$ \\
EEKBM $450 \mathrm{mg} / \mathrm{kg} \mathrm{bb}+$ parasetamol & $528,00 \pm 6,07^{\mathrm{ab}}$ & $803,40 \pm 19,96^{\mathrm{ab}}$ \\
EEKBM $600 \mathrm{mg} / \mathrm{kg}$ bb + parasetamol & $313,70 \pm 9,13^{\mathrm{b}}$ & $472,95 \pm 9,82^{\mathrm{b}}$ \\
\hline
\end{tabular}

Ket : a data berbeda signifikan $(\mathrm{p}<0,05)$ terhadap kelompok tanpa perlakuan.

${ }^{\mathrm{b}}$ data berbedasignifikan $(\mathrm{p}<0,05)$ terhdapkelompok control negative (Na CMC 0,5\%)

Berdasarkan hasil penelitian, EEKBM dosis 300 dan $450 \mathrm{mg} / \mathrm{kg}$ bb mampu menghambat kenaikan kadar ALT dan AST akibat induksi parasetamol dibandingkan kelompok kontrol negatif $(\mathrm{P}<0,05)$, namun efeknya belum sebanding dengan kelompok kontrol positif (rutin $20 \mathrm{mg} / \mathrm{kg}$ bb). Hal ini mungkin dipengaruhi perbedaan komposisi kuersetin, flavonoid yang diyakini memiliki aktivitas hepatoprotektif, tergantung pada bagian dari bawang merah. Kuersetin berada dalam bentuk glukosida (kuesetin 3,4-glukosida, kuersetin-4'-glukosida dan kuersetin-3'glukosida) dengan total 53,5\% di lapisan umbi, sedangkan di kulit terluar kuersetin dalam bentuk aglikon sebanyak $53,2 \%$ [5]. Meskipun aglikon kuersetin yang mempunyai efek antioksidan namun lebih sulit diserap karena sifatnya yang lebih lipofilik sehingga sulit mencapai lapisan dinding usus halus, selain juga karena aglikon tidak stabil pada $\mathrm{pH}$ dan temperatur usus halus. Ikatan gula dengan aglikon membantu meningkatkan absorpsi di usus halus, karena gula yang terikat secara aktif dihidrolisis oleh $\beta$-glukosidase di brush border usus halus yang mempunyai afinitas yang tinggi terhadap glukosida [6]. 
Aktivitas hepatoprotektor EEKBM meningkat seiring peningkatan dosis. Aktivitas EEKBM $600 \mathrm{mg} / \mathrm{kg}$ bb tidak berbeda signifikan dengan kelompok normal. Hal ini menunjukkan EEKBM $600 \mathrm{mg} / \mathrm{kg}$ bb mempunyai efek menghambat peningkatan ALT dan AST yang sebanding dengan kontrol positif (rutin $20 \mathrm{mg} / \mathrm{kg} \mathrm{bb}$ ).

Nilai AST dan ALT merupakan biomarker yang sangat sensitif sehingga dapat digunakan dalam penilaian fungsi hati atau liver test (LT). Apabila membran plasma hepatosit rusak, enzim yang terdapat di sitosol akan keluar menuju aliran darah. Nilai AST yang lebih tinggi dibandingkan ALT mengindikasikan bahwa kerusakan sudah mencapai mitokondria karena AST berada di sitoplasma dan juga mitokondria. Pemeriksaan AST dan ALT biasanya dilakukan untuk menilai tipe dan luas kerusakan sel [7-8].

\subsection{Gambaran makroskopik organ hati}

Hasil menunjukkan adanya perbedaan warna yang cukup jelas pada kontrol negative yaitu organ berwarna coklat muda atau cenderung kuning pucat jikadibandingkan dengan kelompok lainnya, namun tekstur organ dari setiap kelompok perlakuan semuanya tidak terdapat perbedaan yakni memiliki tekstur yang licin (Gambar1)

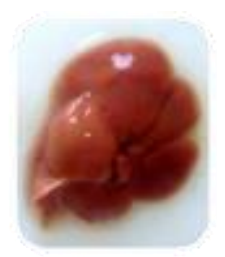

P1

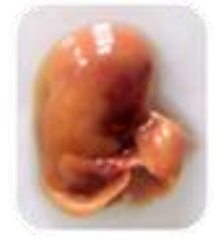

P2

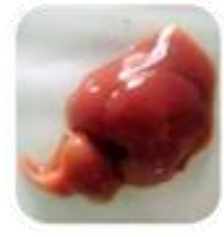

P3

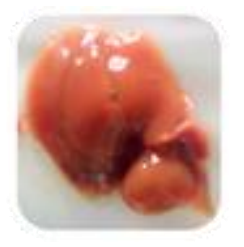

P4

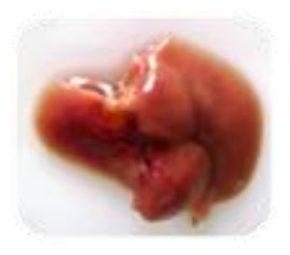

P5

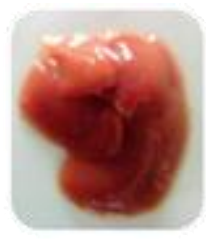

P6

Gambar 1. Pemeriksaan makroskopik organ hati mencit jantan yang diambil setelah didislokasi pada hari ke-15

Keterangan: $\mathrm{P} 1=$ tanpa perlakuan; $\mathrm{P} 2=$ kontrol negatif $(\mathrm{Na} \mathrm{CMC} \mathrm{0,5 \% );} \mathrm{P} 3=$ kontrol positif (rutin $20 \mathrm{mg} / \mathrm{kg} \mathrm{bb}$ );

$\mathrm{P} 4, \mathrm{P} 5, \mathrm{P} 6=\mathrm{EEKBM}$ dosis 300, 450, dan $600 \mathrm{mg} / \mathrm{kg}$ bb

\subsection{Gambaran mikroskopik organ hati}

Berdasarkan analisis histopatologi, kerusakan hepatosit akibat paparan parasetamol dosis toksik dapat ditandai dengan pendarahan yang luas, kongesti vena sentral yang disertai dengan rusaknya endothelium, degenerasi hidropik, nekrosis perivenular, steatosis mikrovesikular dan perubahan inti [9]. Kongesti pada jaringan parenkim hati mencit bisa terjadi sebelum atau sesudah nekrosis. Studi morfologi oleh Walker, dkk. menunjukkan kongesti berasal dari akumulasi sel darah merah ke dalam vakuola endositik dan rongga Disse karena sel endotel sinusoid membengkak dan perfusinya menurun [10]. Degenerasi hidropik atau swelling merupakan tahap awal terjadinya nekrosis yang ditandai dengan hepatosit yang membengkak, di mana terdapat vakuola berbentuk bundar dan berwarna pucat yang disebabkan lumpuhnya aktivitas pompa ion di plasma membran sehingga tidak mempu mempertahankan keseimbangan ion dan cairan [11]. Dilatasi RE merupakan konsekuensi dari meningkatnya aktivitas CYP P450 yang juga menghasilkan spesies oksigen reaktif (ROS) yang nantinya mempengaruhi permeabilitas membran plasma dan menyebabkan swelling. Pada sitoplasma terjadi penumpukan lemak akibat hepatosit yang rusak yang disebut dengan Steatosis mikrovesikular (fatty change) [12]. Kondisi degenerasi hidropik maupun steatosis merupakan perubahan morfologi yang bersifat reversibel, namun dapat berubah menjadi ireversibel apabila disfungsi mitokondria tidak dapat diperbaiki dan mengangguan fungsi membran. Nekrosis perivenular adalah bentuk kematian sel yang terjadi di sekeliling vena, baik vena sentral maupun vena porta. Hal ini dapat terjadi jika dosis obat yang menginduksi nekrosis cukup tinggi, seperti pada penelitian ini di mana dosis parasetamol yang diberikan sebesar $1 \mathrm{~g} / \mathrm{kg}$ bb. Pemilihan dosis pemberian parasetamol $1 \mathrm{~g} / \mathrm{kg}$ bb untuk mencit didasarkan pada penelitian oleh Jaeschke, et al., yang menyimpulkan dosis $\geqslant 200 \mathrm{mg}$ untuk mencit yang dipuasakan dan $\geqslant 400 \mathrm{mg}$ untuk mencit yang tidak dipuasakan mampu menginduksi toksisitas hati yang signifikan. Konversi dosis menunjukkan dosis $1 \mathrm{~g} / \mathrm{kg}$ bb untuk mencit dengan bb $20 \mathrm{~g}$ setara dengan 7,758 $\mathrm{g}$ untuk manusia dengan berat $70 \mathrm{~kg}$ [13]. Hal ini sesuai dengan data klinis di Amerika Serikat di mana dosis tunggal $\geqslant 7,5-10 \mathrm{~g}$ untuk orang dewasa menyebabkan hepatotoksitas dan harus segera dievaluasi dan diberikan intervensi medis [2]. Kerusakan sel dapat 
ditandai dengan adanya perubahan inti akibat pemecahan DNA dan kromatin sehingga inti sel menjadi tersamar (karyolisis), berukuran kecil dan berwarna kehitaman (piknotik), kemudian pecah (karyoreksis) [11].

Gambaran histopatologi EEKBM dosis 300 dan $450 \mathrm{mg} / \mathrm{kg}$ bb masih memperlihatkan ciri nekrosis jika dibandingkan dengan kontrol negatif, walaupun begitu peningkatan dosis ekstrak nyatanya menunjukkan perbedaan. Gambaran histopatologi EEKBM $300 \mathrm{mg} / \mathrm{kg}$ bb menunjukkan pendarahan yang cukup luas yang berawal dari vena sentral kemudian melebar secara radial. Perbesaran 40 × 10 memperlihatkan ekstravasasi eritrosit di sepanjang sinusoid. Steatosis (fatty change) dan degenerasi hidropik juga tersebar di jaringan parenkim hati. Pada gambaran histopatologi EEKBM $450 \mathrm{mg} / \mathrm{kg}$ bb area sentrilobular dan periportal menunjukkan penurunan luas pendarahan dan degenerasi hidropik. Gambaran histopatologi EEKBM $600 \mathrm{mg} / \mathrm{kg}$ bb menunjukkan perbaikan yang signifikan, ditandai dengan degenerasi hidropik yang cukup luas dan vena sentral yang normal dan tidak dijumpai pendarahan.. Gambaran yang bersifat reversibel ini menunjukkan bahwa EEKBM $600 \mathrm{mg} / \mathrm{kg}$ bb mampu menurunkan stres oksidatif sehingga tidak sampai menimbulkan nekrosis perivenular seperti pada kontrol negatif (Gambar 2).
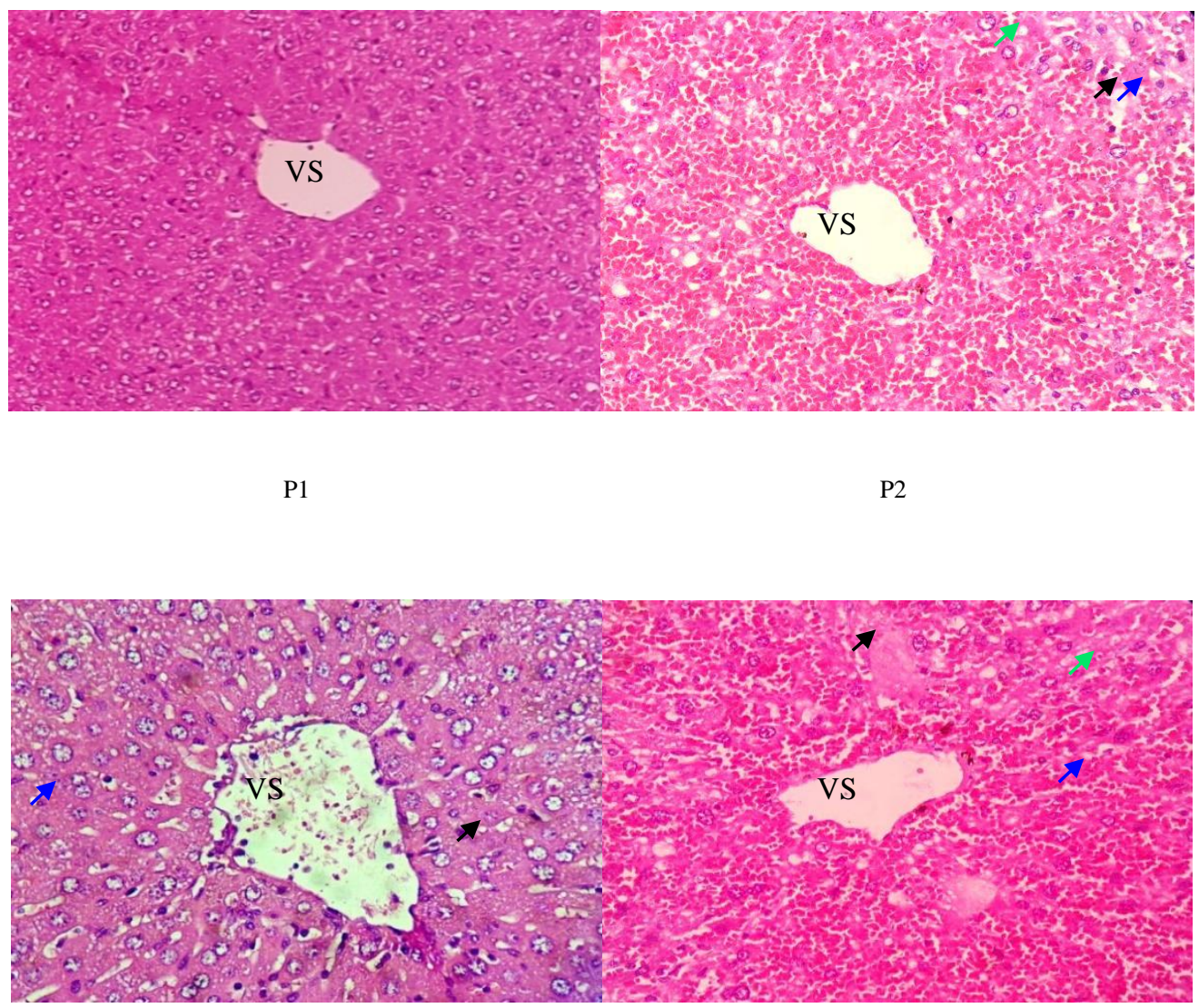


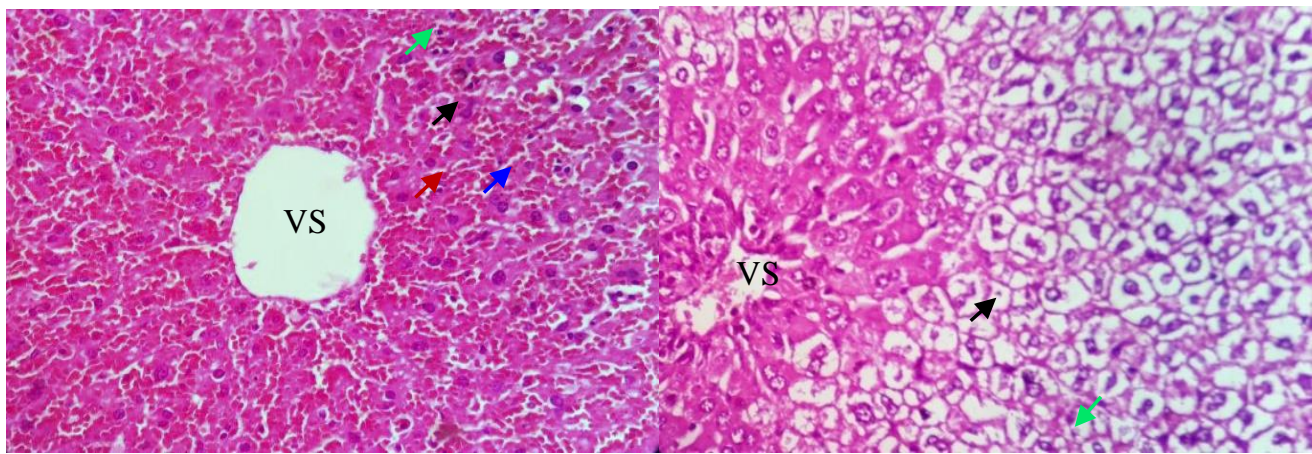

P5

P6

Gambar2. Histopatologijaringanhatimencitjantanperbesaran $10 \times 40$. Cederahatiakibatinduksiparasetamolditandaidenganpendarahan (lingkaran), degenerasihidropik (panahhitam) yang bersifatreversibeldannekrosis yang bersifatireversibeldenganciri inti mengalamipiknosis (panahbiru), karyolisis (panahhijau) dankaryoreksis (panahmerah).Keterangan: P1 = tanpaperlakuan; P2 = kontrolnegatif $(\mathrm{Na}$ CMC 0,5\%); P3 = kontrolpositif (rutin $20 \mathrm{mg} / \mathrm{kg}$ bb); P4,P5,P6 = EEKBM dosis 300, 450, dan $600 \mathrm{mg} / \mathrm{kg}$ bb; VS = vena sentral

\section{Kesimpulan}

Berdasarkan hasil diatas, dapat disimpulkan bahwa EEKBM menunjukkan aktivitas hepatoprotektor terhadap mencit yang diinduksi parasetamol.

\section{Ucapan Terima Kasih}

Penulis mengucapkan terima kasih kepada Laboratorium Kesehatan Daerah Medan yang telah membantu penulis dalam menyelesaikan penelitian ini.

\section{DaftarPustaka}

[1] Agarwal, R., MacMillan-Crow, L.A., Rafferty, T.M., Saba, H., Roberts, D.W., Fifer, E.K., James, L.P., dan Hinson, J.A. (2011). Acetaminophen-Induced Hepatotoxicity in Mice Occurs with Inhibition of Activity and Nitration of Mitochondrial Manganese Superoxide Dismutase. Journal of Pharmacology and Experimental Therapeutic. 337 (1): 110-118.

[2] Bunchorntavakul, C., dan Reddy, K.R. (2013). Acetaminophen-related Hepatotoxicity. Clinical Liver Disease. 17(13): 590.

[3] Skerget, M., Majheniè, L., Bezjak, M., dan Knez, Z. (2009). Antioxidant, Radical Scavenging and Antimicrobial Activities of Red Onion (Allium cepa L.) Skin and Edible Part Extracts. Chemical and Biochemical Engineering Quarterly. 23(4): 435-444.

[4] Ozougwu, J.C., dan Eyo, J.E. (2014). Hepatoprotective Effects of Allium cepa (Onion) Extracts Against Paracetamol-Induced Liver Damage in Rats. African Journal of Biotechnology. 13(26): 2679-2688.

[5] Wiczkowski, W., Nèmeth, N., Buciñski, A., dan Piskula, M.K. (2003). Bioavailability of Quercetin from Flesh Scales and Dry Skin of Onion in Rats. Polish Journal of Food and Nutrition Sciences. 12(53): 95-99.

[6] Graefe, E.U., Wittig, J., Silke Mueller, S., Riethling, A.K., Uehleke, B., Drewelow, B., Pforte, H., Jacobasch, Derendorf, H., dan Veit, M. (2001). Pharmacokinetics and Bioavailability of Quercetin Glycosides in Humans. Journal of Clinical Pharmacology. 41(5): 492-499.

[7] Iyanda, A.A., dan Adeniyi, F.A.A. (2011). Biochemical and Histologic Presentations of Female Wistar Rats Administered with Different Doses of Paracetamol/Methionine. Nigeria Journal of Physiology and Science. 26: 155-156.

[8] Thapa, B.R., dan Walia, A. (2007). Liver Function Tests and Their Interpretation. Indian Journal of Pediatrics.74(7): 665-667.

[9] Sahid, M., dan Subhan, F. (2014). Comparative Histopathology of Acetaminophen Induced Hepatotoxicity in Animal Models of Mice and Rats. Pharmacology Online. 3(33):32-43

[10] Hinson, J.A., Roberts, D.W., dan James, L.P. (2010). Mechanisms of Acetaminophen-Induced Liver Necrosis. Handbook of Experimental Pharmacology. 196(12): 373-374.

[11] Kumar, V., Abbas, A.K., dan Aster, J.C. (2013). Robbin's Basic Pathology. Philadelphia: Elsevier. Hal. 6-9.

[12] Featherstone, B. (2008). Causes of Liver Disease and Dysfunction. Dalam: Drugs and the Liver. Illinois: Pharmaceutical Press. Hal. 5-15.

[13] Jaeschke, H., Williams, C.D., McGill, MR., Xie, Y., dan Ramchandran, A. (2013). Models of Drug-induced Liver Injury for Evaluation of Phytotherapeutics and Other Natural Products. Food Chemistry Toxicology. 5(55): 279-289. 